Прегледни чланак

Márton Leó Zaccaria, Ph.D., Senior Lecturer

University of Debrecen

Faculty of Law

zaccaria.marton@law.unideb.hu

\title{
LAWFUL LIMITATION OF THE RIGHT TO WORK IN THE CONTEXT OF THE FRIES JUDGMENT OF THE COURT OF JUSTICE OF THE EUROPEAN UNION*
}

\begin{abstract}
The present paper examines two main recent issues of the social policy of the European Union (EU). The legal basis of the analysis includes some of the most significant areas of labour law and social law in the European Union. The Court of Justice of the European Union (CJEU) recently has decided some cases regarding the fundamental rights of workers based on the Charter of Fundamental Rights of the European Union and these judgments can mostly raise several concerns related to the interpretation of these rights. It is important that the CJEU has such judgments and it is of high importance that fundamental social rights are considered in these cases. Although, the subject of this paper is the judgment C-190/16, the reasoning and conclusions on the following pages apply to not only this case but also in general regarding the right to work and the prohibition of age discrimination. The lawful or unlawful limitation of these fundamental rights are highlighted because nowadays they mean more than meets the eye, keeping in mind the labour market challenges in the European Union. Consequently, the CJEU has come to important conclusions that have to be interpreted in the context of the recent changes of the social policy of the EU. The paper contains a short outline of the national case and the judgment of the CJEU. The main part of the paper consists of a merit analysis with comments and criticism concerning the limitation to the two emphasised fundamental rights. Conclusions are also included highlighting the importance of the right to work and equal employment in the social and employment policy of the European Union focusing mainly on the freedom to choose an occupation.
\end{abstract}

Keywords: age discrimination, Court of Justice of the European Union, labour law, right to work, workers' rights.

* This paper was supported by the János Bolyai Research Scholarship of the Hungarian Academy of Sciences. 


\section{INTRODUCTION}

The social policy of the European Union (hereinafter: EU) - mainly labour law in a closer sense - is such a legal field which is continuously changing and developing without constant or stable regulation. ${ }^{1}$ This phenomenon has multiplied interpretations, however, the changing legal approach together with the economic and social motivations influence this legal field ${ }^{2}$ which basically defines the image of the normative fundamental rights. This phenomenon is more modulated by the case law of the Court of Justice of the European Union (hereinafter: CJEU), since it has interpreted individual social rights in several judgments for decades, this way continuously forming a kind of dynamic concept of the social protection for workers. The European Pillar of Social Rights (EPSR) realised in 2017 can change these procedures, ${ }^{3}$ furthermore, the reforrms as a consequence can have direct effects on the subjects of the labour market. ${ }^{4}$ At the same time, it would not be advisable to view only the future when we study such entitlements that basically define the interests of the employees like the subject of the present study, namely the right to work and the requirement of equal treatment. ${ }^{5}$ I think in this respect the Charter of Fundamental Rights of the European Union (hereinafter: CFREU) which came into force on 1 December 2009 and became part of primary EU law, significantly changed the image of the legal protection of the employees. This study selects from the circle of these rights focusing on an actual resolution of the CJEU, which can be definitely regarded as a keynote debate. On the following pages, I will examine some relevant aspects to such legal anomalies focusing on two of the most fundamental rights of workers in EU law through a recent judgment of the CJEU. ${ }^{6}$

\section{BACKGROUND - MAIN POINTS OF THE NATIONAL CASE}

Mr. Werner Fries, as aeroplane commander, had an employment relationship with Lufthansa from 1986 to 31 December 2013 when his effective employment

\footnotetext{
${ }^{1}$ Antoine Jacobs, "Labour Law, Social Security Law and Social Policy After the Entering Into Force of the Treaty of Lisbon", European Labour Law Journal, 2/2011, 131-137.

${ }^{2}$ Frank Hendrickx, "Editorial: The European pillar of social rights - Interesting times ahead”, European Labour Law Journal, 3/2017, 191.

${ }^{3}$ See in details: European Pillar of Social Rights, https://ec.europa.eu/commission/sites/ beta-political/files/social-summit-european-pillar-social-rights-booklet_en.pdf, 30 July 2018.

${ }^{4}$ Frank Hendrickx, "The European Social Pillar: A first evaluation", European Labour Law Journal, 1/2018, 3-5.

${ }^{5}$ See: Predrag Jovanović, „The Principle of Equality in Labour Law“, Collected papers Faculty of Law Novi Sad, 1/2018, 17-26; and Predrag Jovanović, „Current Aspects of the Principal of Protecting Employees“, Collected papers Faculty of Law Novi Sad, 3/2011, 143-149

${ }^{6}$ C-190/16. Werner Fries v Lufthansa CityLine GmbH [2017] ECLI:EU:C:2017:513.
} 
relationship was terminated according to the regulation of the applicable German collective agreement. Termination was compulsory as regulated in the collective agreement after Mr. Fries became 65 years old, since he reached the retirement age in the compulsary retirement system; consequently, his further employment was impossible. ${ }^{7}$ However, Mr. Fries on the basis of his employment contract did not work only as a commander but also took part in training the young pilots, so this activity could be regarded a kind of supplementary working activity and not his main duty. ${ }^{8}$

Two months before the termination of the employment contract, namely, from 31 October 2013 the employer did not employ the employee though his employment relationship was valid formally until 31 December 2013 according to the labour contract. Essentially, this was the injurious act, since his employment relationship was terminated only two months later, but he could not work as pilot over 65 years of age referring to the sub para. b) of FCL.065 of I. Annex of the 1178/2011 Regulation ${ }^{9}$ since it is strictly forbidden in air transport with commercial purposes. Although, Mr. Fries offered his contractual completion/performance in labour relationship, his employer referring to his age did not fulfill the employer's employment obligation in spite of the fact that the employee had the necessary valid commercial pilot licences. Mr. Fries thinks that he suffered labour law infringement since he could not work as pilot after the age of 65 and referring to this his employment relationship terminated on 31 December 2013.

\section{THE JUDGMENT OF THE COURT OF JUSTICE OF THE EUROPEAN UNION IN CASE C-190/16.}

From the articles of the CFREU arts. 21, 15 and 22 applied in the case; the first two articles in connection with the legal protection of the employee, and the latter one in connection with its restriction. In its justification, the CJEU regards restrictive regulation such a regulation that may infringe both the right to free choice of employment and the equal treatment, even though through the examination the CJEU had to start from their possible limitation.

Art. 21 of the CFREU definitely states the prohibition of age discrimination, which is stated by the CJEU together with art. 20 of the CFREU referring to the generality and unity of the regulation. ${ }^{10}$ Referring to all these the CJEU firstly

\footnotetext{
${ }^{7}$ Points $18-20$ of the judgment C-190/16.

${ }^{8}$ Point 17 of the Advocate General's opinion for the judgment C-190/16.

${ }^{9}$ Commission Regulation (EU) No 1178/2011 of 3 November 2011 laying down technical requirements and administrative procedures related to civil aviation aircrew pursuant to Regulation (EC) No 216/2008 of the European Parliament and of the Council.

${ }^{10}$ Points 29-33 of the judgment C-190/16.
} 
clears generally and principally what should be regarded as equal and unequal treatment. The essence of this interpretation is the basically important paradigm of the principle that similar situations should be treated similarly and different situations should be treated differently. ${ }^{11}$ Consequently, the CJEU in points 34-35 of the judgment declares that prohibition of working as a pilot at the age of 65 implements discrimination based on age, but it does not automatically mean the invalidity of point $b$ ) of the challenged regulation, because referring to the para 1 of art. 52 of the CFREU justification of different treatment must be analysed.

Referring to the abridgment the CJEU states that the age regulation for the pilots is declared in law; it is proportional and does not affect the essence of the fundamental right declared in art. 21 of the CFREU. According to the CJEU, the compliance of these criteria undoubtedly justifies that restriction for the employees over the age of 65 implements lawful different treatment, but not age discrimination. Futhermore, the CJEU interpreted that this restriction does not have an effect on the essence of the principle of the equal treatment, since it has restrictive effect only in a narrow circle on a certain personal circle, consequently, it does not weaken the consistent performance of arts. 21 and 20 of the CFREU. ${ }^{12}$ Public interest supports the legality of the aim of resctriction, ${ }^{13}$ namely, it seems that the EU legislator really considered the listed aspects referring to working performance of the pilots in commercial air traffic. However, the point is whether the legal aim is combined with the proportional limitation of fundamental rights without going beyond the necessary measure. We may speak about a directive, which is legal according to the Directive 2000/78/EC, ${ }^{14}$ e.g. the aims of employment policy, but its consequence may be disproportional and unnecessary restriction, ${ }^{15}$ and in such cases, clear different treatment cannot be granted exemption. The CJEU performed this examination in points 45 and 46 of the Decision and came to the conclusion that the resolution on restricting the pilot's employment on the basis of his age is proper/correct and proportional and performs proportional restriction and does not go beyond the necessary measure.

Point 51 of the judgment states a part of the conclusion in connection to the fact that limitation of fundamental rights on grounds of age primarily serves the compliance with the provision of the EU requirements of air safety, namely, it is a basically important requirement for the pilots to be - without doubt - physically

\footnotetext{
${ }^{11}$ Point 28 of the judgment C-236/09. Association Belge des Consommateurs Test-Achats ASBL and Others v Conseil des ministres [2011] I 00773.

${ }^{12}$ Point 38 of the judgment C-190/16.

${ }^{13}$ Points $42-43$ of the judgment C-190/16.

${ }^{14}$ Council Directive 2000/78/EC of 27 November 2000 establishing a general framework for equal treatment in employment and occupation.

${ }^{15}$ See as a typical example the conclusion of the judgment C-286/12. European Commission v Hungary [2012] ECLI:EU:C:2012:687.
} 
fit for work without any danger to life and physical or personal integrity. Nevertheless, to fulfil the requirements of physical criteria is harder when you get older. Consequently, the CJEU declares it justified that a differentiation e should be made clearly among the pilots on the basis of their age, since the listed criteria essentially are the requirements of the position of a pilot and tasks in connection to it, so the proportionality of the regulation is rather supported than confuted on the basis of the interests which are in the background of age limitation (guarantee of safety of integrity and property). The CJEU considered the disadvantages because of which the group of employees suffered, and considered the advantages that are the consequences of these limitations on the societal level. ${ }^{16}$

However, it is still a matter of concern as to why 65 years is the limit and why the EU legislator defined the final and ex lege exclusion without consideration and transition, e.g. compulsory medical examination schould be required. The CJEU states that medical and scientific uncertainties cannot undermine the coherence of the relevant regulation; similarly, the legislator is not obliged to take every exemption and every individual case into consideration. ${ }^{17}$ The CJEU complements this interest and states that according to point 52 of the cited Dominica Petersen judgment ${ }^{18}$ to justify the consistency of the abridging regulation regarding one's age is adequate if a certain age can be regarded as "sufficiently old", so the legal background of this limitation also can be made by generality. To strengthen these arguments the CJEU mentions that the "rule of age of 65" does not result in the persons concerned being cut out from all possible access to the labour market, moreover, this rule does not mean the automatic termination of the employment relationship. ${ }^{19}$

Referring to the limitation of art. 15 of the CFREU the CJEU declares inter alia that the right to work is not a limitless or absolute fundamental right, and it can only be interpreted in accordance with its societal designation, like the right to property, and it can be limited only by public interest and proportionality. ${ }^{20}$ Furthermore, according to point 75 of the C-190/16. judgement the strict age limitation does not affect the essence of the fundamental right to free choice of work, since it restricts the right to work only over 65 for a narrow personal circle, so it cannot be regarded as a restriction of the tackled fundamental right's essence. In points 77 and 78 the CJEU comes to the conclusion that this regulation is

16 Point 38 of the judgment C-141/11. Torsten Hörnfeldt v Posten Meddelande AB [2012] ECLI:EU:C:2012:421 and point 73 of the judgment C-45/09. Gisela Rosenbladt v Oellerking Gebäudereinigungsges. mbH [2010] I 09391.

${ }^{17}$ Points 60-62 of the Advocate General's opinion for the judgment C-190/16.

${ }^{18}$ C-341/08. Domnica Petersen v. Berufungsausschuss für Zahnärzte für den Bezirk Westfalen-Lippe [2007] ECR I 0047.

19 Point 40 of the judgment C-141/11. Torsten Hörnfeldt v Posten Meddelande AB [2012] ECLI:EU:C:2012:421.

${ }^{20}$ Point 73 of the judgment C-190/16. 
suitable to strike a balance between the interests that should be protected by the primary law (freedom to choose occupation and public security), and it performs proportional limitation as it was interpreted above. The CJEU does not list any further arguments about the content of the right to work and its limitation, consequently, it states that based on restractibility of the mentioned fundamental rights the final and automatic exclusion of a certain personal circle from employment, as pilot because of age does not affect the very content of the art. 15 of the CFREU, so, similarly to the interpretation referring to art. 21 , it performs legal and proportional limitation of a fundamental right on the side of the concerned group of employees. The relevant national collective agreement declared on point $b$ ) of the regulation on which basis the employee as a pilot cannot work over 65 in transport air traffic and referring to it his employment relationship automaticly terminated without attention to whether she or he already reached pension rights or not does not infringe EU law, neither the right to free choice of work, nor the prohibiton of age discrimination.

\section{COMMENTARY ON THE JUDGMENT REGARDING THE RIGHT TO WORK AND PROHIBITION OF AGE DISCRIMINATION}

Firstly, on interpreting arts. 15 and 21 of the CFREU the CJEU regarded only some relevant aspects, so in spite of the fact that the CJEU had to take a position on limitation of these two fundamental rights, some aspects were left without attention. It is important because the resolution suggests that the CJEU intends to regulate principally the limitation of the right to work and about the exceptions from the prohibition of age discrimination, however, we think that the essential elements of these two rights did not receive enough attention in the judgment. In connection to the latter, we would like to emphasise that both Directive 2000/78/ EC and the diversified role of the CJEU's case law connected to it seem to be unclear in a case of a fundamental rights nature, which also reflects uncertainty in legal interpretation. This issue will be interpreted in more detail later. Altogether, I would like to add the circumstance that the CJEU on applying fundamental social or labour rights did not make progress, even though; it could hardly be expectable taking into consideration the circumstances of the case.

It cannot be denied that difficulties being discovered so far in the application of the CFREU in cases of social policy, ${ }^{21}$ even if these difficulties can be observed

${ }^{21}$ See in details: Gyula Berke: “Az Európai Unió Alapjogi Chartájának alkalmazása munkajogi (szociálpolitikai) ügyekben”, HR \& Munkajog, 11/2013, 8-14.; Edit Kajtár, Franz Marhold, "The Principle of Equality in the Charter of Fundamental Rights and Age Discrimination", European Labour Law Journal, 4/2016, 321-342.; Sara Iglesias Sánchez, “The Court and the Charter: The Impact of the Entry into Force of the Lisbon Treaty on the ECJ's Approach to Fundamental 
in the questions of the legal application and limitation, but necessarily in questions of content of the relevant fundamental rights. ${ }^{22}$ This way we would not like to "exempt" totally the CJEU from the responsibility of not trying to interpret the discussed fundamental rights in a more abstract, developing way, or at least, to state an interpretation reflecting teleology ${ }^{23}$ while the General Advocate's opinion of the case - contrary to the judgment - is trying to insert such concerns. Basically, the CJEU follows the argumentation of the General Advocate, so it seems unpleasant to leave further arguments without attention, since they could complete the standpoint and the final resolution of the CJEU. The distance of the CJEU from the content of arts. 15 and 21 of the CFREU may be criticised referring to Advocate General Bobek's detailed proposal. In my opinion, it can be criticised since some important ideas from the opinion could have been applied by the CJEU as well and could have strengthened the arguments of the judgment itself. However, the opinion does not suggest a final decision with adverse content, but several concerned legal interpretations and questions can be seen. Even if we accept the judgment of the CJEU regarding the content and nature of the two analysed fundamental rights, it would be expedient that the CJEU should have applied these elements for the reasoning and justification more definitely.

A good example of it is the interpretation of the restriction of the right to work, which was forgotten by the CJEU, apart from general justification of restriction based on para. 1 of art. 52 of the CFREU. However, the opinion itself does not contain many more arguments, but states some relevant legal interpretations, which the CJEU should not have left without attention. Otherwise, the arguments of point 69 of the opinion can be criticised, and it is also necessary to mention them in this sense. Although, the CJEU itself alludes to why the "rule of

Rights", Common Market Law Review, 5/2012, 2565-2611.; Veronica Papa, “The Dark Side of Fundamental Rights Adjudication? The Court, the Charter and the Asymmetric Interpretation of Fundamental Rights in the AMS Case and Beyond", European Labour Law Journal, 3/2015, 190199. and Massimiliano Delfino, "The Court and the Charter - A "Consistent,, Interpretation of Fundamental Social Rights and Principles”, European Labour Law Journal, 1/2015, 86-99.

${ }^{22}$ The CFREU is not applicable on its own for the sake of fundamental right protection if there is no secondary legislation in EU law concerning the certain articles. See: Tamás Gyulavári, Gábor Kártyás, "Effective international enforcement of employee rights? Challenging Hungarian 'unorthodox' laws", European Labour Law Journal, 2/2018, 118-120. See also the relevant case-law of the CJEU regarding the socially significant art. 30: C-332/13. Weigel v Nemzeti Innovációs Hivatal (ECLI: EU: C:2014:31), C-614/12. and C-10/13. joined cases Dutka v Mezogazdasági és Vidékfejlesztési Hivatal and Sajtos vs Budapest Föváros VI. Kerületi Önkormányzata (ECLI: EU: C:2014:30), C-488/12., C-489/12., C-490/12., C-491/12. and C-526/12. joined cases Nagy v HajdúBihar Megyei Kormányhivatal, Böszörményi Gálóczhi-Tömösváry and Szabadosné Bay v Mezőgazdasági és Vidékfejélesztési Hivatal, Ványai v Nagyrábé Község Polgármesteri Hivatala (ECLI: EU: C:2013:703).

${ }^{23}$ Although, the Advocate General also refers to this matter in points 95-98 of the Advocate General's opinion for the judgment C-190/16. 
age of 65 " does not limit the essence of the fundamental right to free choice of work, ${ }^{24}$ but I regard it as important that this conclusion can be clearly deduced from the opinion. Furthermore, in points 74-76 of the proposal, even if on a questionable theoretical basis, the General Advocate summarises the above mentioned ideas about the restriction of the right to work as part of the conclusion; these arguments are missing from the conclusions of the same content of the CJEU (such argument is e. g. the lack of the direct relationship between the forced termination of the employment relationship and pension rights).

In the following, I am going to analyse - with criticism - the deficiencies of the argument referring to "the essence of the important content" of art. 15 of the CFREU and the deficiences of the merit conclusions. In my opinion, the CJEU did not analyse the right to freedom to choose occupation in spite of the fact that in this case the fundamental right nature of this right was one of the central actors. In spite of the fact that content questions were reduced to the background, the CJEU paid more attention to the restriction of the right to work, which caused a kind of argumental imbalance in the decision. Although we should not forget the social nature of fundamental social rights in $\mathrm{EU} \mathrm{law}^{25}$ it means that on analysing them we cannot apply the same standard as in the international labour law environment, or the structure of fundamental rights in general, or the national labour laws. Still, social and labour rights, which are accepted in the form of fundamental rights, ${ }^{26}$ cannot remain terra incognita when analysing and restricting art. 15 of the CFREU. These common, universal values can be summed up on the economic, social and human right side of the right to work.

This "two-faced" right makes the examination harder, since in this case not every aspect have the same weight, but according to the argument of the advocate general the essence of art. 15 has to state the directions and measure of restriction while taking into consideration para. 1 of art. 52 of the CFREU. Obviously, in the concept accepted nowadays of the right to work the economic side dominates, ${ }^{27}$ since it is not an absolute subjective right and its enforcement against the state has actual boundaries, but it does not mean that the social side should be ignored. ${ }^{28}$ The two aspects - mainly in the present case - must be enforced in

${ }^{24}$ Points 38 and 72 of the judgment C-190/16.

${ }^{25}$ Stefano Guibboni, "Social Rights and Market Freedom in the European Constitution: A Re-Appraisal”, European Labour Law Journal, 2/2010, 164-169. and Bob Hepple, "Fundamental Social Rights since the Lisbon Treaty", European Labour Law Journal, 2/2011, 150-154.

${ }^{26}$ Christophe Vigneau, "7. Freedom to Choose an Occupation and Right to Engage in Work (Article 15)", European Labour Law and the EU Charter of Fundamental Rights (ed. Brian Bercusson), Nomos, Baden-Baden 2006, 173-175. and 181-186.

${ }^{27}$ György Kiss, Alapjogok kolliziója a munkajogban, JUSTIS, Pécs 2010, 275-276.

${ }^{28}$ Mostly because of the social nature of labour law: Nóra Jakab, "On the significance of the employee status and of the personal scope of labour law regulation", Novi Sad Faculty of Law Collected Papers, 3/2016. 998-999. 
parallel, since Mr. Fries's right to work is restricted from the economic side because of seriously narrowing his possibilities in employment, while on the social side disadvantages in the labour market which are a consequence of his age and which are not compensated by the legislator are linked to his right to work. Consequently, I disagree with the argument, according to which this kind of restriction of art. 15 is not disproportionate, since it does not affect the essence of the right to work, ${ }^{29}$ because its restriction refers only to certain professions at certain ages and is not valid "in general". The circumstance that a certain limitation of legislation refers "only" to a group of employees of a certain profession, does not prove the lack of important restriction, since limitation is undoubtedly important for this group of employees.

In my opinion, compulsory termination of a given professional career is an essential limitation, but of course, it does not mean automatically that the regulatory limitation is unlawful, but mutatis mutandis, it raises the general question as to whether (how) the right to work could be restricted at all. Furthermore, the fact that the above mentioned abridgment refers only to one profession but not to all professions in general, and prohibits employment of only one profession for people over 65, seems to be an incomplete argument. Although, it is true that these persons can take any kind of job, but based on their earlier professional experiences, age, and previous steps in their careers their possibilities become very much limited according to my view. Therefore, this limitation affects the essential content of art. 15. It is also important that pension rights are not necessarily assured after this kind of termination or forced termination of the employment relationship, consequently, the employees of older age would get into a helpless situation in the labour market regarding both their right to work and the guarantee of social security. The discussed regulatory limitation affects the essence of the challenged fundamental right this aspect, too.

A contrario one may ask whether what kind of and what amount of limitation affects the essence of the right to work if that regulation in the present case cannot affect it in merit. In my opinion the essence of the freedom to choose occupation is diversified, ${ }^{30}$ however, an interpretation according to which automatic and final disclosure of a given group from the continuation of a profession on the basis of age exclusively, but not on the basis of e.g. professional ability, is not essential,

${ }^{29}$ However, this aspect is not strictly related to this paper's topic, I mention the human right side of the right to work; consequently, it is very important to proceed with caution when judging and restricting its essential content. See: Virginia Mantouvalou, "Are Labour Rights Human Rights?", European Labour Law Journal, 2/2012, 152-154.

${ }^{30}$ Free movement of workers and their right to social security are also part of the right to work. The linear connections between the aforementioned fundamental rights are emphasised in judgment C-284/15. Office national de l'emploi (ONEm) v M and M v Office national de l'emploi (ONEm) and Caisse auxiliaire de paiement des allocations de chômage (CAPAC) [2016] ECLI:EU:C:2016:220. 
and may result contra legem legal interpretation. It is confirmed since the central element of this question in the argument of both the Advocate General and the judgment is that this limitation refers only to a small number of clearly defined people, but I think that the discussed limitation restricts the right to work of all the persons who are over 65 and can potentially fulfil the requirements of pilots working in air transport. This standpoint can be directly connected to the requirement of equal treatment, since EU law does not prohibit discrimination, but guarantees the principle of equal treatment; ${ }^{31}$ consequently, the basis is not the question to whom the given regulation is discriminative, but whether the given regulation ensures equal opportunities for everybody. In connection to the free choice of occupation, we think, that point 76 of the Advocate General's opinion is contradictory - although, the CJEU refers to it in the judgment - since it calls para. 1 of art. 15 "yardstick for review of validity", and "interpretative guideline". In case of such important and clear limitation of a fundamental right it should have interpreted more strictly and concentrated on the essence of this fundamental right instead.

Summing up, it can be stated that on examining the content and possible limitation of art. 15 the CJEU left without attention the importance of the fundamental right nature of the workers' rights, however, their limitation is possible, but not in such unambiguous way and not regarding its merit content. Otherwise, the right to work plays an extremely important role among these fundamental social and economic rights, implicitly; the decision suggests that the standpoint of the CJEU regarding the protection of the employees is not moving into the direction of a more effective legal protection. ${ }^{32}$

I think that the following argument is misleading and reflects contra legem legal interpretation: the regulation limiting the pilots in their work designates a general standard, and the function of this standard does not essentially restrict this fundamental right. Additionally, the prohibition refers only to the employees over 65, so, this regulation does not limit the essential rights of older employees in merit. ${ }^{33}$ Additionally, I would like to criticise the lawful proportionality of the limitation, because it is hard to judge proportionally a strict regulation without exemptions, which contains automatic prohibition. In this regard, it does not count how many people who are at least 65 are affected by this prohibition (see the above mentioned theoretical possibility of individual medical and/or professional test). On the one hand, regarding the performance and exemption of discrimination it can hardly be accepted that only a small number of people of a certain age are

${ }^{31}$ Dagmar Schiek, "The ECJ Decision in Mangold: A Further Twist on Effects of Directives and Constitutional Relevance of Community Equality Legislation", Industrial Law Journal, 3/2006, 329-341.

${ }^{32} \mathrm{M}$. Delfino, 98-99.

${ }^{33}$ Points $62-63$ and $72-78$ of the judgment C-190/16. 
affected by the restriction - see the above stated in connection to art. 15 of the CFREU - and on the other hand, proportionality is not necessarily limited to deliberate necessity and appropriateness regarding the examined regulatory limitation the CJEU states in point 51 that the above mentioned system of arguments "appears likely to strengthen rather than weaken" the proportionality of the action, ${ }^{34}$ consequently, this way the adequacy of the regulation is questioned.

According to my opinion, this uncertainty in legal interpretation weakens the convincing strength of the exemption argument, so the most important question, namely, why is it necessary to restrict the pilots' right to work just at the age of 65 and why without exemption and deliberation, is not answered clearly. Additionally, in point 66 of the judgment it is clear that CJEU is not convinced totally that $\mathrm{Mr}$. Fries and other pilots in a similar situation suffer disadvantage in the labour market, since law discloses them from performing only one profession and only at the time they are approaching the end of their career. Furthermore, this regulation causes implicit but not direct disadvantage to the employee we can also speak about the danger of indirect discrimination, even if according to the concept of the Directive the basic case definitely belongs to the conceptual circle of the direct discrimination. ${ }^{35}$ Otherwise, these real disadvantages are proved since the employee has the possibility of continuing the employment relationship after the age of 65 , unlike in the case of Mr. Fries, but the employment is refused for the period while the employment relationship is really terminated, or the employee becomes entitled to pension rights, so disadvantage may be performed even during the employment relationship.

Finally, it can be stated that in spite of the great limitation it is not sure that with the given regulation the aim - ensurement of the safe air transport protecting public security - would be achieved. The lack of examination of the individual eligibity indicates that generalisation is the only reasonable explanation for compulsary prohibition right over 65 , since the Member States, the social partners, or even the employers could have possibilities to consider the relevant issues. It is important referring to the Petersen judgment, ${ }^{36}$ since the acceptance of the necessary measure can be disregarded too, since this kind of limitation of staying in employment can be debated regarding the question of necessity and proportionality.

\section{CONCLUSIONS}

In my opinion, the present decision is important from two points of view. On the one hand, referring to the interpretation of the fundamental rights in the

\footnotetext{
${ }^{34}$ Point 51 of the judgment C-190/16.

${ }^{35}$ Points 29-34 of the judgment C-190/16.

${ }^{36}$ With reference to points $42-43$ of the Advocate General's opinion for the judgment C-190/16.
} 
CFREU, their practical appearance, and their concrete limitation expresses important consequences, and on the other hand, two fundamental workers' rights, the right to work and the prohibition of age discrimination definitely appear in it. ${ }^{37}$ It is important to add that regarding the extent and essence of the fundamental rights the CJEU sates in the decision at several places that it is not a real limitation of any fundamental right and it does not influence the essence of the challenged fundamental rights if the abridgment applies only for a smaller group or for a narrowly interpreted type of employment relationship, similarly to the practice when the Directive 2000/78/EC was used to analyse the content of art. 21 of the CFREU. It is very substantial that the CJEU establishes a special dynamic relationship between secondary legal acts and certain articles of the CFREU.

This dynamism in interpretation in this case may result in several contradictions referring to arts. 15 and 21 of the CFREU, furthermore, the importance of this case is clear, since the CJEU seems to declare more and more definitely that the protective rules of employment discrimination based on age should be regarded as flexible and the reality of the labour market also should increasingly be accepted . Naturally, clear citation of the regulations of the public order and public security basically modulates the picture, but in general the attitude of the CJEU towards some actual facts of the labour market can be observed, e.g. obtaining pension rights, possibilities of employment in older age, access to certain professions, which stimulates the discussions. Referring to the restriction of the right to work as a fundamental social right a further question rises: can such significant and open restriction be inducted only by reasons of public order and public security or can other aspects induct it, too? If the answer is "yes", the CJEU in the future will have to pay special attention to this aspect in the context of legal protection of workers and the fundamental rights guaranteed in the CFREU.

Summing up, in the future the latter circumstances can be influenced by the new axioms of social and/or employment policy, and labour law in the framework of the EPSR as well as the new tendencies in labour law regulation and the fundamental rights of employees. However, in this potential discussion it may play an important role that another new judgment appeared in which the CJEU interpreted two fundamental rights of social - and economic - nature.

\footnotetext{
${ }^{37}$ Naturally, equal treatment based on age is not an exclusive right for workers but because of labour market realities - meaning the employers' negative approach to employing older people - workers are more precarious regarding age discrimination. See: T. Gyulavári, G. Kártyás, 123124.
} 


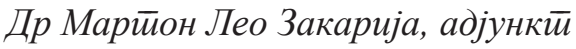

Универзитетету у Дебрецину

Правни факулиетеи

zaccaria.marton@law.unideb.hu

\section{Границе права на рад у контексту пресуде Суда правде Европске уније у предмету Fries v Lufthansa CityLine GmbH}

Сажеейак: У чланку ирред вама, сиироведена је анализа два акииуелна ииийаға у домену соиијалне иолитиике Евройске уније (у даљем йексу: ЕУ),

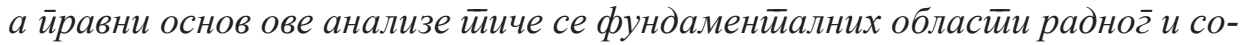
иијалног йрава ЕУ. У ближој иромилостии, Суд ирравде Евройске уније (у даљем иекксйу: Суд) је у неколико йредметиа одлучивао о фундаменииалним ирравима зайослених која су уйврђена у Повељи о основним иравима ЕУ (у даљем

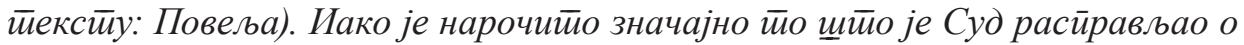
фундаментиалним ирравима, ирресуде у тиим случајевима оивварају низ йийаюь у вези са схвайанем и иррименом йојединих иррава йредвиђених Повељом. Премда је анализа ирредмейних иичйања у овом чланку базирана на йресуди

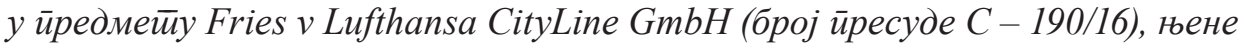

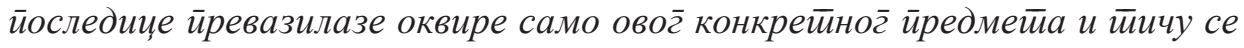
зайраво ииийања (огрраничења) иррава на рад и забране дискриминације йо основу гоодина живойа у ЕУ. Питиағе огрраничења ових фундамениталних йрава данас је од йосебног̄ значаја нарочит̄о имајући у виду изазове са ко-

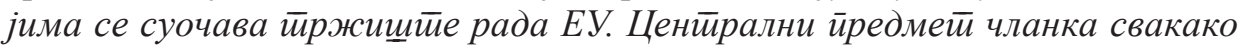

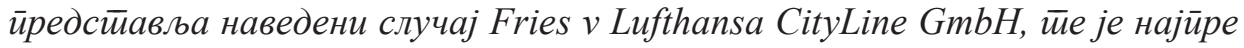
дай кроки йриказ овог сйора који се водио ирред националним судом државе чланице (Немачка), а йойом је анализирана ирресуда Суда у овом ирредмейу. На крају, изнетии су наши закључии у йоглледу значаја йрава на рад и једна-

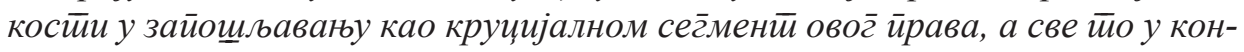

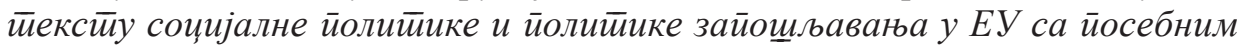
осврииом на слободу избора занимања.

Кључне речи: дискриминачија йо основу гоодина живойа, Суд йравде Евройске уније, радно ирраво, йраво на рад, иррава радника.

Датум пријема рада: 08.08.2018. 